\title{
Effect of Thermal Treatment on Combustion Process of Spruce Wood (Picea abies)
}

\section{Učinak toplinske obrade na proces izgaranja drva smreke (Picea abies)}

\author{
Original scientific paper • Izvorni znanstveni rad \\ Received-prispjelo: 18. 9. 2017. \\ Accepted-prihvaćeno: 13. 6. 2018. \\ UDK: $630 * 812.582 ; 674.032 .13$ \\ doi:10.5552/drind.2018.1752
}

\begin{abstract}
This paper deals with the effect of thermal treatment of spruce wood on its burning process. Samples of $100 \mathrm{~mm} \times 100 \mathrm{~mm}$ were dried out and then heat-treated at $150{ }^{\circ} \mathrm{C}, 200{ }^{\circ} \mathrm{C}, 250{ }^{\circ} \mathrm{C}$ and $300{ }^{\circ} \mathrm{C}$. Thus prepared samples were tested on a cone calorimeter at a heat flow of $50 \mathrm{~kW} \cdot \mathrm{m}^{-2}$. The obtained results clearly show that with the increasing temperature of the treatment, the released heat from the surface unit decreases and the unit weight increases. The carbon dioxide concentration in the flue gas increases as well, however, the optical density of the smoke decreases substantially. It can be stated that the burning of spruce wood is considerably affected mainly by the thermal treatment at temperatures above $200^{\circ} \mathrm{C}$. From the point of view of the use of spruce wood as fuel, the most optimal treatment temperature is $250^{\circ} \mathrm{C}$.
\end{abstract}

Key words: torrefaction, Picea abies wood, heat flux, heat release

SAŽETAK • U radu se razmatra učinak toplinske obrade smrekova drva na proces njegova gorenja. Uzorci dimenzija $100 \times 100 \mathrm{~mm}$ osušeni su i zatim toplinski obrađeni na 150, 200, 250 i $300{ }^{\circ} \mathrm{C}$. Tako pripremljeni uzorci ispitani su na konusnom kalorimetru, pri toplinskom toku od $50 \mathrm{~kW} \cdot \mathrm{m}^{-2}$. Iz dobivenih se rezultata može uočiti da se s povećanjem temperature toplinske obrade smanjuje oslobođena toplina površinske jedinice i povećava jedinična težina uzoraka od smrekovine. Koncentracija ugljikova dioksida u dimnom plinu također se povećava, ali se optička gustoća dima znatno smanjuje. Može se također zaključiti da na izgaranje smrekovine uglavnom znatno utječe toplinska obrada pri temperaturama višim od $200{ }^{\circ} \mathrm{C}$. S gledišta upotrebe smrekovine kao ogrjeva, optimalna je temperatura toplinske obrade tog drva $250^{\circ} \mathrm{C}$.

Ključne riječi: torefakcija, drvo smreke, toplinski tok, otpuštanje topline

\section{INTRODUCTION \\ 1. UVOD}

The treatment of wood by thermal load can be divided into three basic areas on the basis of the required output raw material. Drying is intended to reduce wood moisture. It is usually performed at a temperature of up to $115^{\circ} \mathrm{C}$ (Edvardsen and Sandland, 1999; Hansson and Antti, 2006; Zarea Hosseinabadi et al., 2012; Sehlstedt-Persson, 1995). The second area is thermal modification.

Modern thermal modification processes are limited to temperatures no higher than $260^{\circ} \mathrm{C}$. As a result of thermally induced chemical changes to the macromolecular constituents, the physical and biological properties of wood are altered (Hill, 2007). Finally, wood is used for the preparation of torrefied wood. This semi refined material is an intermediate between

\footnotetext{
${ }^{1}$ Authors are assistants at Slovak University of Technology in Bratislava, Faculty of Materials Science and Technology in Trnava, Slovak Republic.

Autori su asistenti Slovačkoga tehnološkog sveučilišta u Bratislavi, Fakultet za znanost i tehnologiju materijala, Trnava, Slovačka.
} 
wood and charcoal, which has undergone a mild pyrolysis in inert atmosphere, at temperatures from 200 ${ }^{\circ} \mathrm{C}$ to $300{ }^{\circ} \mathrm{C}$ and atmospheric pressure (Bourgois and Guyonnet, 1988).

Thermal decomposition of wood can be described using a five-reaction mechanism, consisting of three devolatilization reactions for the pseudo-components - hemicellulose, cellulose and lignin, and of two additional reactions in the air for char devolatilization and combustion (Broström et al., 2012).

Heat-treatment affects the mechanical properties of wood, whereby hardwood species are more susceptible to this process than softwood. The decay resistance of heat-treatment may be achieved but at a high cost and with reduced mechanical properties (Kamdem et al., 2002). Heat treatment mainly resulted in a darkening of wood tissues, improvement of the dimensional stability of wood and reduction of its mechanical properties (Bekhta and Niemz, 2003). Increased heat treatment and resulting weight loss reduce the modulus of rupture (MOR) and modulus of elasticity (MOE) (Mburu et al., 2008). Živković et al. (2008) state that the results of laboratory tests show that the heat-treated wood, when compared to genuine wood, except of improvements in dimensional stability, also exhibits a lower equilibrium moisture content in room conditions. Results of Mburu et al. (2007) showed that resistance to fungi and termites was greatly improved by the treatment. The acidity and wood-water contact angle are higher and polar component of surface free energy is lower after thermal modification (Miklečić and Jirouš-Rajković, 2016).

A mild thermal treatment (modifying at 160 - 180 ${ }^{\circ} \mathrm{C}$ in oxygen-poor atmosphere) leads to clear changes of the measurable acoustic characteristics, such as Young's modulus, damping and sound velocity, so thermally modified wood is a material with favourable characteristics for making musical instruments (Pfriem, 2015).

As a solid energy carrier, biomass generally has a few disadvantages, which limits its use for coal replacement and as a feedstock for entrained flow gasification. The hydrophilic and fibrous nature, low calorific value and low bulk energy content imply high accumulated costs in the whole supply chain and severe challenges in more advanced conversion systems. By thermally pre-treating the biomass by torrefaction, these properties may be significantly improved (Strandberg et al., 2015), so torrefaction is a promising technique for improving the biomass performance for energy utilization (Tapasvi et al., 2012).

In contrast to fossil fuels, biomass has a unique potential for making positive environmental impact. In the plan of the sustainable biomass production and use, the carbon dioxide emitted would be absorbed by newly grown biomass. It can be burnt without emitting large amounts of nitrogen oxides, and with low emissions of sulphur dioxide (Quaak et al., 1999).

During torrefaction, the main thermal decomposition reactions involve the hemicellulose polymers, resulting in improved fuel properties exhibited by the torrefied samples. Compared to raw samples, the com- position of the torrefied samples is closer to that of coal, with higher carbon content and a lower volatile matter content, and with much higher hydrophobicity (Tapasvi et al., 2012). The carbon contents of torrefied wood are greater than those of wood, but lower than those of charcoal. Carbon increases at the expense of oxygen and hydrogen, thus leading to decreases in both $\mathrm{H} / \mathrm{C}$ and $\mathrm{O} / \mathrm{C}$ ratios (Pentananunt et al., 1990).

In comparison to non-thermally treated wood, torrefied biomass fuels contain a lower amount of volatile matter and a higher amount of fixed carbon (Ndibe et al., 2015).

Both torrefaction temperature and reaction time have strong effects on the torrefaction process, but temperature effects are stronger than effects of reaction time (Tran et al., 2013; Felfli et al., 2005; Pimchuai et al., 2010).

It was demonstrated that the weight loss of thermally modified wood is mostly the result of the reduction of the polysaccharide fraction, while hemicelluloses degraded faster than cellulose during heat exposure. The acid-insoluble lignin content increased with the severity of the treatment at the expense of the carbohydrate component. (González-Peña et al., 2009) Similar results are described by Čabalová et al. (2013). Upon thermal decomposition of spruce wood with increasing temperature, the amount of lignin and the amount of extracts increased, but the abrasive layer had a decrease in extracts. At the same time, the polysaccharide fraction degraded significantly, the average polymerization degree of cellulose decreased where the crosslinking reactions occurred. The results of Calonego et al. (2016) show that the thermal modification of wood causes significant increases in the net calorific value, and the extractive content, and significant decreases in the holocellulose, galactose, xylose and glucose contents.

At higher temperatures, wood shrinks in the transversal plane, due to volatilization of wood constituents and due to a slight densification of the cell wall substance (González-Peña et al., 2009).

The torrefaction process can also be applied to wood-based fuels. In terms of torrefied product properties, the torrefied samples absorb approximately onethird of the moisture compared to the raw fuels, and the total grinding energy decreases up to $40-88 \%$ (Tapasvi et al., 2012).

Degradation of hemicelluloses, cellulose and lignin and removing of moisture from the material, have a strong effect on the pelletizing properties of biomass. The friction in the press channel of a pellet mill increases, resulting in high pelletizing pressures that increase the energy uptake of the mill and might result in a decrease of capacity and in worst case in overheating of a blockage of the mill press channels (Stelte et al., 2011). The common practice in pelletizing of thermally untreated biomass, using water to decrease energy consumption and to improve bonding properties, is not applicable in pelletizing of torrefied materials (Larsson et al., 2013). The composition of torrefied briquettes at $220{ }^{\circ} \mathrm{C}$ does not undergo many changes. 
However, at higher temperatures, changes in the composition are perceptible, with the briquette hemicellulose practically degraded and cellulose depolymerisation process initiated (Felfli et al., 2005).

According to the report of the Ministry of Agriculture and Rural Development of the Slovak Republic and the National Forest Centre, in the year 2016, 9.3 mil. $^{3}$ of wood was produced, of which $55.2 \%$ was wood of coniferous trees. During this period, the production of spruce was $61.6 \%$ of coniferous trees. A large amount of spruce timber was significantly affected by the activation of harmful biotic agents (Moravčík et al., 2017). Usually such a contaminated wood is not suitable for construction or furniture purposes and it can be used for energy purposes. Therefore, this paper deals with the possibilities of thermal treatment of spruce and its influence on the burning of the resulting material.

\section{MATERIALS AND METHODS 2. MATERIJALI I METODE}

For the measurements, 5 sample pieces of tangentially split spruce wood (Picea abies (L.) Karst.) with dimensions of $100 \mathrm{~mm}$ x $100 \mathrm{~mm}$ and $20 \mathrm{~mm}$ thickness were used. The samples were first dried to zero humidity at $102{ }^{\circ} \mathrm{C}$ for 48 hours. Subsequently, four of them were further thermally treated at $150{ }^{\circ} \mathrm{C}$, $200{ }^{\circ} \mathrm{C}, 250{ }^{\circ} \mathrm{C}$ and $300{ }^{\circ} \mathrm{C}$ in a preheated furnace. The heat treatment was carried out for 4 hours in a muffle furnace under an inert atmosphere (nitrogen flow rate of $\left.200 \mathrm{ml} \cdot \mathrm{min}^{-1}\right)$. Finally, the samples were transferred to an exsicator, where they cooled down to ambient temperature. The total time of procedure was approximately 55 hours (48 hours for drying, 4 hours of thermal treatment at appropriate temperature, approximately 3 hours for cooling). The percentage mass loss of samples due to their thermal treatment is shown in Figure 1. With the increase of treatment temperature, the weight loss of the sample also increases. RamosCarmona et al. (2017) attribute this phenomenon to hemicellulose and cellulose decomposition and to oxidation reactions. Barta-Rajnai et al. (2017) also describe strong decrease of the volatile extractive content. Since the spruce samples were thermally treated in a nitrogen atmosphere, the oxidation reactions did not occur and, therefore, it was possible to predict the effect of decomposition of the mentioned wood components.

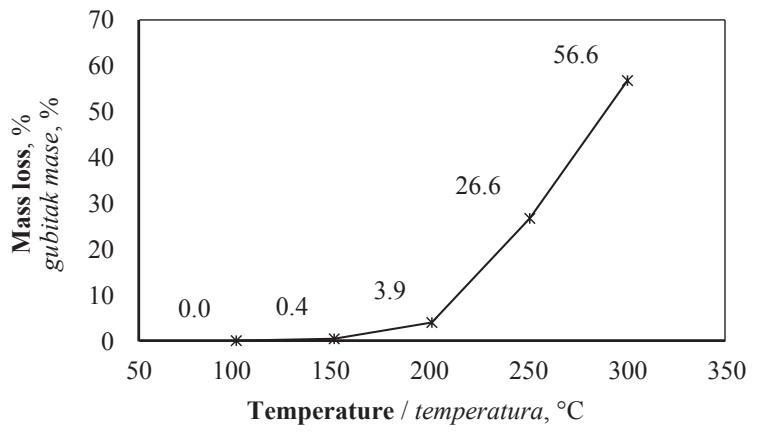

Figure 1 Dependence of the percentage mass loss on the temperature of thermal treatment

Slika 1. Ovisnost postotnoga gubitka mase o temperaturi toplinske obrade

The measurements were made on cone calorimeters meeting ISO standards 5660-1 (2015). Although a higher number of samples is required for the measurement of wood materials, due to the heterogeneous nature of wood, for cone calorimeter measurements the use of one sample for one heat flux is common, as evidenced by other authors. The samples were placed in the horizontal position under the emitter and initiation of the combustion was provided by an electric spark initiator. The measurement conditions are shown in Table 1 . The time to ignition of the samples, the amount of heat released, the concentrations of carbon oxides in the flue gas and the amount of smoke released were observed.

\section{RESULTS AND DISCUSSION}

3. REZULTATI I RASPRAVA

The rate of heat release (Figure 2) is very similar for most samples. There is almost no oxidation of the sample material before initiation of flame burning. Volatile flammable substances are released, while the concentration of these substances in the mixture with air does not reach the value required for their ignition. This first phase takes a relatively short time, which can be attributed in particular to high external heat flow. As soon as the rate of release of the flammable fuel is sufficient, initiation occurs. Due to rapid homogeneous burning, the rate of heat release increases sharply. Once the sharp peak has been reached, a hardened layer begins to form on the surface of the samples. This acts as an insulator and partially restricts the heating of the

Table 1 Measurement conditions for individual samples

Tablica 1. Uvjeti mjerenja za pojedine uzorke

\begin{tabular}{|l|c|c|c|c|c|}
\hline Treatment temperature, ${ }^{\circ} \mathrm{C} /$ Temperatura obrade, ${ }^{\circ} \mathrm{C}$ & 100 & 150 & 200 & 250 & 300 \\
\hline Ambient temperature, ${ }^{\circ} \mathrm{C} /$ Temperatura okoline, ${ }^{\circ} \mathrm{C}$ & 23 & 23 & 23 & 23 & 23 \\
\hline Barometric pressure, $\mathrm{Pa} /$ Barometarski tlak, $\mathrm{Pa}$ & 101054 & 101030 & 100977 & 100771 & 100768 \\
\hline Relative air humidity, $\%$ / Relativna vlažnost zraka, $\%$ & 21 & 20 & 20 & 20 & 20 \\
\hline External heat flux, $\mathrm{kW} \cdot \mathrm{m}^{-2} /$ Vanjski toplinski tok, $\mathrm{kW} \cdot \mathrm{m}^{-2}$ & \multicolumn{5}{|c|}{50} \\
\hline Nominal duct flow rate, $\mathrm{dm}^{3} \cdot \mathrm{s}^{-1} /$ Nominalna brzina protoka, $\mathrm{dm}^{3} \cdot \mathrm{s}^{-1}$ & \multicolumn{5}{|c|}{5} \\
\hline Sampling interval, $\mathrm{s} /$ Interval uzorkovanja, $\mathrm{s}$ & \multicolumn{5}{|c|}{25} \\
\hline Separation, $\mathrm{mm} /$ Odvajanje, $\mathrm{mm}$ & \multicolumn{5}{|c|}{0.04296} \\
\hline C-factor / C-faktor & \multicolumn{5}{|c|}{} \\
\hline
\end{tabular}




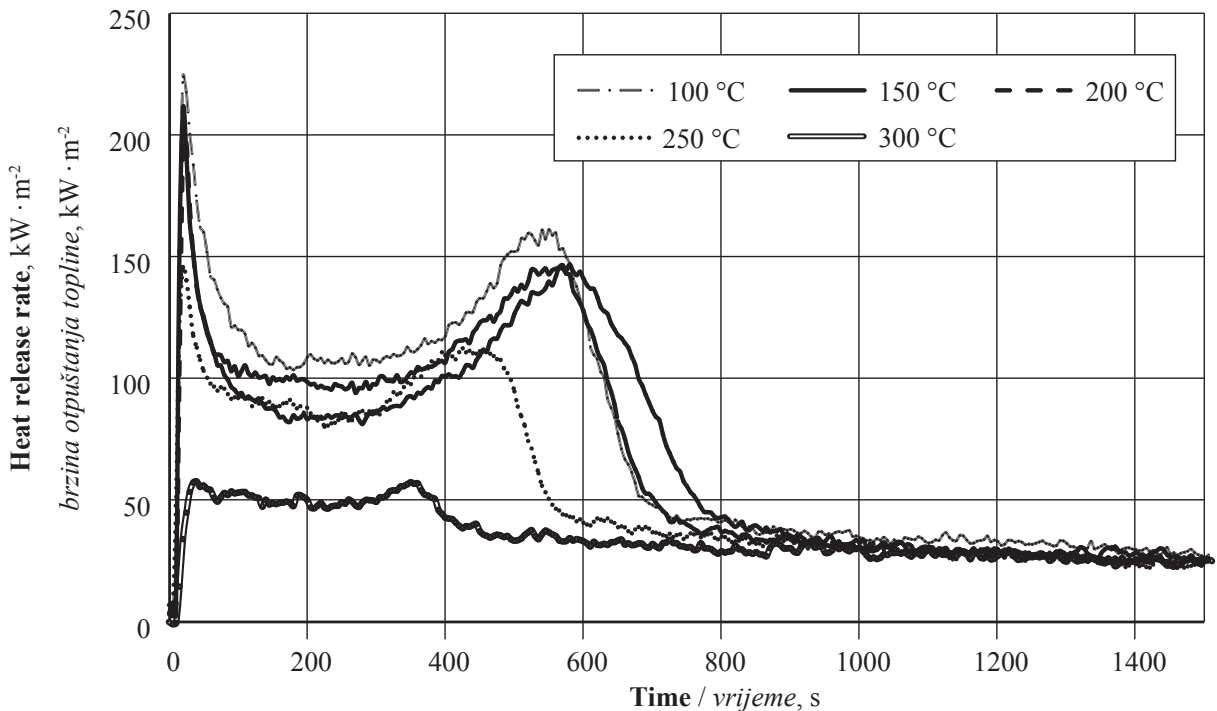

Figure 2 Time of heat release rate in combustion process of thermally-treated spruce wood

Slika 2. Vremenski tijek brzine otpuštanja topline u procesu izgaranja toplinski obrađene smrekovine

rest of the sample. At the same time, it partially prevents the penetration of volatile flammable substances into the burning area. Both of these mechanisms cause a decrease in the rate of heat release up to the phase of combustion stabilization. This area is visible in the graph in the form of a constant course. Then, it is followed by the second, considerably lower and wider peak. Hagen et al. (2009) state for the wood that the second peak occurs when the thermal wave reaches the back-insulating surface and the original material has already been pre-heated to the pyrolysis temperature, thereby effectively reducing the heat of the pyrolysis. After the flame burning, the rate of heat release decreases sharply. There are stages of smouldering and glowing, in which the heat is released mainly by the oxidation of carbon residues. The same course of burning in cone calorimetry testing has also been reported by Janssens (1991).

As the temperature of the thermal treatment increases, the value of both the first and the second peak decreases (Table 2). This decrease was also noted by Martinka et al. (2016) for spruce timber treated by different processes. Due to the high susceptibility of hemicelluloses to thermal degradation compared to lignin described by various authors (Mburu et al., 2008; Mburu et al., 2007; Calonego et al., 2016), this phenomenon can be attributed to the gradual thermal decomposition of hemicelluloses and cellulose in wood during the preparation of samples. In this way, the proportion of volatile flammable fuel, which is a fuel for homogeneous combustion, is declining. Burning of the specimen heated at $300{ }^{\circ} \mathrm{C}$ has a specific course, where both the first and the second peak do not reach any sharp maximum and only slightly differ from the steady burning phase.

In the samples treated thermally at temperatures of $250{ }^{\circ} \mathrm{C}$ and $300{ }^{\circ} \mathrm{C}$, relatively faster rate of combustion starts to show up, which has also been stated by Pentananunt et al. (1990) for wood treated at similar temperatures $\left(250{ }^{\circ} \mathrm{C}-270{ }^{\circ} \mathrm{C}\right)$.

In terms of the initiation phase, an important parameter is the average rate of heat release in the first 60 seconds. For a spruce panel measured on a cone calorimeter, Östman et al. (1985) indicate a value of 172 $\mathrm{kW} \cdot \mathrm{m}^{-2}$. The dried spruce was measured with a very similar result at a level just above $166 \mathrm{~kW} \cdot \mathrm{m}^{-2}$ (Figure 3 ). It is clear from the other measurements that the first-minute average heat release rate decreases, with

Table 2 Results of thermally treated samples of spruce wood

Tablica 2. Rezultati toplinski obrađenih uzoraka smrekovine

\begin{tabular}{|c|c|c|c|c|c|}
\hline Treatment temperature, ${ }^{\circ} \mathrm{C} /$ Temperatura obrade, ${ }^{\circ} \mathrm{C}$ & 100 & 150 & 200 & 250 & 300 \\
\hline Time to ignition, s / Vrijeme do zapaljenja, $\mathrm{s}$ & 9 & 8 & 8 & 8 & 12 \\
\hline First peak HRR $*, \mathrm{~kW} \cdot \mathrm{m}^{-2} /$ Prvi vrh $H R R^{*}, \mathrm{~kW} \cdot \mathrm{m}^{-2}$ & 223.76 & 210.17 & 196.49 & 145.44 & 57.25 \\
\hline Second peak HRR $*, \mathrm{~kW} \cdot \mathrm{m}^{-2} /$ Drugi vrh $H R R^{*}, \mathrm{~kW} \cdot \mathrm{m}^{-2}$ & 160,81 & 146,45 & 144,95 & 112,07 & 59,97 \\
\hline TSR $* *, \mathrm{~m}^{2} \cdot \mathrm{m}^{-2}$ & 343.17 & 225.35 & 194.07 & 103.46 & 3.65 \\
\hline Mean HRR*, $\mathrm{kW} \cdot \mathrm{m}^{-2} /$ Srednja vrijednost $H R R^{*}, \mathrm{~kW} \cdot \mathrm{m}^{-2}$ & 65.90 & 60.09 & 60.09 & 48.40 & 32.64 \\
\hline Mean $\mathrm{EHC}^{* * *}, \mathrm{MJ} \cdot \mathrm{kg}^{-1} /$ Srednja vrijednost EHC ${ }^{* * *}, \mathrm{MJ} \cdot \mathrm{kg}^{-1}$ & 16.23 & 15.84 & 16.76 & 17.38 & 21.84 \\
\hline Mean MLR M***$^{*} \mathrm{mg} \cdot \mathrm{s}^{-1} /$ Srednja vrijednost $M L R^{* * * *}, \mathrm{mg} \cdot \mathrm{s}^{-1}$ & 35.89 & 33.52 & 31.70 & 23.62 & 12.53 \\
\hline Mean CO yield, $\mathrm{mg} \cdot \mathrm{g}^{-1} /$ Srednja vrijednost prinosa $C O, \mathrm{mg} \cdot \mathrm{g}^{-1}$ & 27.36 & 28.60 & 28.88 & 44.70 & 80.12 \\
\hline Mean $\mathrm{CO}_{2}$ yield, $\mathrm{g} \cdot \mathrm{g}^{-1} /$ Srednja vrijednost prinosa $\mathrm{CO}_{2}, \mathrm{~g} \cdot \mathrm{g}^{-1}$ & 1.35 & 1.34 & 1.43 & 1.52 & 1.81 \\
\hline $\mathrm{THR}^{* * * * *}, \mathrm{MJ} \cdot \mathrm{m}^{-2}$ & 118.57 & 108.07 & 108.07 & 87.15 & 58.67 \\
\hline
\end{tabular}

*Heat Release Rate / brzina oslobađanja topline; **Total Smoke Release / ukupno ispuštanje dima; ***Effective Heat of Combustion / učinkovita toplina izgaranja; ****Mass Loss Rate / brzina gubitka mase; $* * * * *$ Total heat release / ukupno oslobađanje topline 


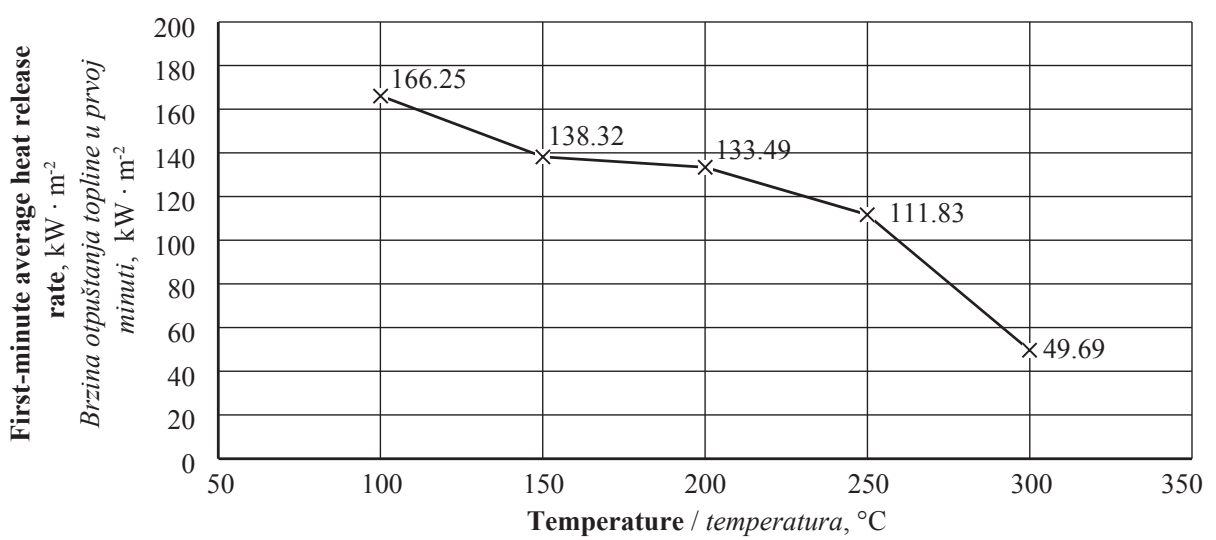

Figure 3 Influence of thermal treatment temperature on the first-minute average heat release rate in combustion of spruce wood

Slika 3. Utjecaj temperature toplinske obrade drva na brzinu otpuštanja topline u prvoj minuti izgaranja smrekovine

the temperature growth of the thermal spruce treatment, which is mainly due to the declining heat release rate. The decrease in the first peak of the heat release rate is also directly related to the decreasing maximum heat release energy (Table 2), which is an important indicator for the first phase of fire propagation.

The treatment temperature had a strong effect on total smoke release (Table 3). While dried wood released a smoke during the flame corresponding to an optical density of $345 \mathrm{~m}^{2} \cdot \mathrm{m}^{-2}$, the wood torrefied at 300 ${ }^{\circ} \mathrm{C}$ no longer showed any smoke. Similar results were described by different authors. Pentananunt et al. (1990) indicate that the torrefied wood showed significantly less smoking during combustion compared to untreated wood. Felfi et al. (2005) state that, from the combustion point of view, decreases in $\mathrm{O} / \mathrm{C}$ and $\mathrm{H} / \mathrm{C}$ ratios are favorable since less smoke and water vapour are formed, improving the performance of briquettes and contributing to energy loss reduction. The release of less smoke can be attributed to a gradual change in the soot formation mechanism in samples undergoing the process of thermal treatment (Mitchell et al., 2016).

Results of individual measurements are shown in Table 2. The time for sample ignition does not show a large diffusion in the specimens modified to $250{ }^{\circ} \mathrm{C}$. The value of $8 \mathrm{~s}$ to $9 \mathrm{~s}$ is comparable to that reported for spruce by Östman et al. (1985) Initiation of the sample modified at $300{ }^{\circ} \mathrm{C}$ occurred slightly later than in the previous samples. Due to the very low peak of heat release rate and the visual observation at which the flame did not differ from other samples, it is clear that the amount of volatile combustible in the sample was small. Initiation of volatile flammable mixtures with air was, therefore, delayed.

Mean heat release rate per unit area and hence a total heat release does decrease with the increasing temperature of the treatment. However, since the heat treatment changes the weight of the samples, the mean effective heat of combustion increases. This result is consistent with the calorific value of wood due to thermal treatment (Calonego et al. 2016). At the same time, the yield of carbon dioxide and carbon monoxide increases. This is probably due to the higher carbon content of thermally modified wood compared to the orig- inal material described in the literature (Pentananunt et al., 1990).

\section{CONCLUSION}

4. ZAKLJUČAK

The previous thermal treatment in an inert atmosphere has a notable influence on burning spruce wood. The influence occurs partly already before the sample initiation, which is higher compared to other specimens in the case of the sample modified at the temperature of $300{ }^{\circ} \mathrm{C}$. The heat release rate reaches lower maximum values with the increasing adjustment temperature and its course is getting balanced. Intensity as well as flame burning time decrease as a result of decreasing flammable fuel content. However, in the case of thermal treatment, the weight of the sample also decreases, resulting in an increase in effective heat of combustion. The burning rate showed a sharp increase in samples treated at $250^{\circ} \mathrm{C}$ or higher. In terms of flammability, the increase in the temperature of the heat treatment was confirmed by its decrease. In the case of torrefied wood, this is almost a hundredfold change, which can be considered very positive when used as a fuel. It can be concluded that the notable change in the burning of the treated wood is caused mainly by temperatures of thermal treatment above $200^{\circ} \mathrm{C}$. The highest amount of heat released per unit mass, substantially lower total smoke release, and the most uneven heat release during burning was observed in the sample thermally treated at the temperature of $300{ }^{\circ} \mathrm{C}$. However, since the heat release rate in this sample reaches values very close to the external thermal flux applied to its surface, from the point of view of the use of spruce wood as a fuel, the preferred treatment temperature appears to be $250{ }^{\circ} \mathrm{C}$.

\section{Acknowledgments - Zahvala}

This research was supported by the Slovak Research and Development Agency under the contract No. APVV-0057-12.

This work was supported by the KEGA under the contract No. 030UMB-4/2017 and under the contract No. 012TU Z-4/2016. 


\section{REFERENCES}

\section{LITERATURA}

1. Barta-Rajnai, E.; Wang, L.; Sebestyén, Z.; Barta, Z.; Khalil, R.; Skreiberg, Ø.; Grønli, M.; Jakab, E.; Czégény, Z., 2017: Comparative study on the thermal behavior of untreated and various torrefied bark, stem wood, and stump of Norway spruce. Applied energy, 204: 10431054. https://doi.org/10.1016/j.apenergy.2017.05.057

2. Bekhta, P.; Niemz, P., 2003: Effect of high temperature on the change in color, dimensional stability and mechanical properties of spruce wood. Holzforschung, 57: 539-546. https://doi.org/10.1515/HF.2003.080

3. Bourgois, J.; Guyonnet, R., 1988: Characterization and analysis of torrefied wood. Wood science and Technology, 22: 143-155. https://doi.org/10.1007/BF00355850

4. Broström, M.; Nordin, A.; Pommer, L.; Branca, C.; Di Blasi, C., 2012: Influence of torrefaction on the devolatilization and oxidation kinetics of wood. Journal of analytical and applied pyrolysis, 96: 100-109. https://doi.org/10.1016/j.jaap.2012.03.011

5. Cabalová, I.; Kačík, F.; Kačíková, D.; Oravec, M., 2013: The influence of radiant heating on chemical changes of spruce wood. Acta Facultatis Xylologiae Zvolen, 55: 59-66.

6. Calonego, F. W.; Severo, E. T.; Sansígolo, C. A.; Rezende, M. A.; Bruder, E. M.; Costa, V. E., 2016: Calorific value and chemical properties in juvenile and mature wood of thermally-modified Eucalyptus Grandis. Drvna industrija, 67: 207-214. https://doi.org/10.5552/drind.2016.1522

7. Edvardsen, K.; Sandland, K. M., 1999: Increased drying temperature - Its influence on the dimensional stability of wood. European Journal of Wood and Wood Products, 57: 207-209. https://doi.org/10.1007/s001070050042

8. Felfli, F. F.; Luengo, C. A.; Suárez, J. A.; Beatón, P. A., 2005: Wood briquette torrefaction. Energy for Sustainable Development, 9: 19-22.

9. González-Peña, M. M.; Curling, S. F.; Hale, M. D., 2009: On the effect of heat on the chemical composition and dimensions of thermally-modified wood. Polymer Degradation and Stability, 94: 2184-2193. https://doi. org/10.1016/j.polymdegradstab.2009.09.003

10. Hagen, M.; Hereid, J.; Delichatsios, M. A.; Zhang, J.; Bakirtzis, D., 2009: Flammability assessment of fire-retarded Nordic Spruce wood using thermogravimetric analyses and cone calorimetry. Fire Safety Journal, 44: 1053-1066. https://doi.org/10.1016/j.firesaf.2009.07.004

11. Hansson, L.; Antti, A. L., 2006: The effect of drying method and temperature level on the hardness of wood. Journal of Materials Processing Technology, 171: 467470. https://doi.org/10.1016/j.jmatprotec.2005.08.007

12. Hill, C. A., 2007: Wood modification: chemical, thermal and other processes. John Wiley \& Sons.

13. ***ISO 5660-1: 2015: Reaction to fire tests, Heat release, smoke production and mass loss rate, Part 1: Heat release rate (cone calorimeter method) and smoke production rate (dynamic measurement).

14. Janssens, M., 1991: Rate of heat release of wood products. Fire safety journal, 17: 217-238. https://doi. org/10.1016/0379-7112(91)90003-H

15. Kamdem, D. P.; Pizzi, A.; Jermannaud, A., 2002: Durability of heat-treated wood. European Journal of Wood and Wood Products, 60: 1-6. https://doi.org/10.1007/s00107-001-0261-1

16. Larsson, S. H.; Rudolfsson, M.; Nordwaeger, M.; Olofsson, I.; Samuelsson, R., 2013: Effects of moisture content, torrefaction temperature, and die temperature in pilot scale pelletizing of torrefied Norway spruce. Applied energy, 102: 827-832.

https://doi.org/10.1016/j.apenergy.2012.08.046
17. Martinka, J.; Kacíková, D.; Rantuch, P.; Balog, K., 2016: Investigation of the influence of spruce and oak wood heat treatment upon heat release rate and propensity for fire propagation in the flashover phase. Acta Facultatis Xylologiae Zvolen res Publica Slovaca, 58: 5-14.

18. Mburu, F.; Dumarçay, S.; Bocquet, J. F.; Petrissans, M.; Gérardin, P., 2008: Effect of chemical modifications caused by heat treatment on mechanical properties of Grevillea robusta wood. Polymer degradation and stability, 93: 401-405.

https://doi.org/10.1016/j.polymdegradstab.2007.11.017

19. Mburu, F.; Dumarçay, S.; Huber, F.; Petrissans, M.; Gérardin, P., 2007: Evaluation of thermally modified Grevillea robusta heartwood as an alternative to shortage of wood resource in Kenya: characterisation of physicochemical properties and improvement of bio-resistance. Bioresource Technology, 98: 3478-3486. https://doi.org/10.1016/j.biortech.2006.11.006

20. Miklečić, J.; Jirouš-Rajković, V., 2016: Influence of Thermal Modification on Surface Properties and Chemical Composition of Beech Wood (Fagus sylvatica L.). Drvna industrija, 67: 65-71. https://doi.org/10.5552/drind.2016.1520

21. Mitchell, E. J. S.; Lea-Langton, A. R.; Jones, J. M.; Williams, A.; Layden, P.; Johnson, R., 2016: The impact of fuel properties on the emissions from the combustion of biomass and other solid fuels in a fixed bed domestic stove. Fuel processing technology, 142: 115-123. https://doi.org/10.1016/j.fuproc.2015.09.031

22. Moravčík, M.; Kovalčík, M.; Bednárová, D.; Halvoň, L.; Kaštier, P.; Kunca, A.; Longauerová, V.; Miková, A.; Oravec, M.; Pajtík, J.; Pavlenda, P.; Sarvašová, Z.; Schwarz, M., 2017: Report on Forestry in the Slovak Republic for 2016. Ministry of Agriculture and Rural Development of the Slovak Republic; National Forest Centre, $68 \mathrm{p}$.

23. Ndibe, C.; Maier, J.; Scheffknecht, G., 2015: Combustion, cofiring and emissions characteristics of torrefied biomass in a drop tube reactor. Biomass and bioenergy, 79: 105-115.

https://doi.org/10.1016/j.biombioe.2015.05.010

24. Östman, B.; Svensson, I. G.; Blomqvist, J., 1985: Comparison of three test methods for measuring rate of heat release. Fire and Materials, 9: 176-184. https://doi.org/10.1002/fam.810090406

25. Pentananunt, R.; Rahman, A. M.; Bhattacharya, S. C., 1990: Upgrading of biomass by means of torrefaction. Energy, 15: 1175-1179. https://doi.org/10.1016/0360-5442(90)90109-F

26. Pfriem, A., 2015: Thermally modified wood for use in musical instruments. Drvna industrija, 66: 251-253. https://doi.org/10.5552/drind.2015.1426

27. Pimchuai, A.; Dutta, A.; Basu, P., 2010: Torrefaction of agriculture residue to enhance combustible properties. Energy \& Fuels, 24: 4638-4645. https://doi.org/10.1021/ef901168f

28. Quaak, P.; Knoef, H.; Stassen, H. E., 1999: Energy from biomass: a review of combustion and gasification technologies. World Bank technical paper no. WTP 422, Energy series, Washington, D.C.: The World Bank. https:// doi.org/10.1596/0-8213-4335-1

29. Ramos-Carmona, S.; Delado-Balcázar, S.; Perez, J. F., 2017: Physicochemical characterization of torrefied wood biomass under air as oxidizing atmosphere. BioResources, 12: 5428-5448.

https://doi.org/10.15376/biores.12.3.5428-5448

30. Sehlstedt-Persson, S. M., 1995: High-temperature drying of Scots pine, A comparison between HT-and LT-drying. 
European Journal of Wood and Wood Products, 53: 9599. https://doi.org/10.1007/BF02716400

31. Stelte, W.; Clemons, C.; Holm, J. K.; Sanadi, A. R.; Ahrenfeldt, J.; Shang, L.; Henriksen, U. B., 2011: Pelletizing properties of torrefied spruce. Biomass and Bioenergy, 35: 4690-4698.

https://doi.org/10.1016/j.biombioe.2011.09.025

32. Strandberg, M.; Olofsson, I.; Pommer, L.; WiklundLindström, S.; Åberg, K.; Nordin, A., 2015: Effects of temperature and residence time on continuous torrefaction of spruce wood. Fuel Processing Technology, 134: 387-398. https://doi.org/10.1016/j.fuproc.2015.02.021

33. Tapasvi, D.; Khalil, R.; Skreiberg, Ø.; Tran, K. Q.; Grønli, M., 2012: Torrefaction of Norwegian birch and spruce: an experimental study using macro-TGA. Energy \& Fuels, 26: 5232-5240. https://doi.org/10.1021/ef300993q

34. Tran, K. Q.; Luo, X.; Seisenbaeva, G.; Jirjis, R., 2013: Stump torrefaction for bioenergy application. Applied Energy, 112: 539-546.

https://doi.org/10.1016/j.apenergy.2012.12.053
35. Zarea Hosseinabadi, H.; Doosthoseini, K.; Layeghi, M., 2012: Drying kinetics of poplar (Populus deltoides) wood particles by a convective thin layer dryer. Drvna industrija, 63: 169-176.

https://doi.org/10.5552/drind.2012.1201

36. Živković, V.; Prša, I.; Turkulin, H.; Sinković, T.; JiroušRajković, V., 2008: Dimensional stability of heat treated wood floorings. Drvna industrija, 59: 69-73.

\section{Corresponding address:}

Ing. PETER RANTUCH, Ph.D.

Department of Integrated Safety

Faculty of Materials Science and Technology in Trnava

Slovak University of Technology in Bratislava, Botanická 49

91724 Trnava, SLOVAKIA

e-mail: peter.rantuch@stuba.sk 